OPEN ACCESS

Edited by:

Yenchun Jim Wu,

National Taiwan Normal University,

Taiwan

Reviewed by:

$B \circ L V$,

Shenyang Normal University, China Juanita Mcneil,

Southern University and A\&M College,

United States

*Correspondence:

Ying Jiang

duwhgd@126.com

Specialty section:

This article was submitted to

Educational Psychology,

a section of the journal

Frontiers in Psychology

Received: 15 June 2021 Accepted: 13 October 2021 Published: 18 November 2021

Citation:

Wang $W$ and Jiang $Y$ (2021)

Influence of Entrepreneurial

Psychology and Spirit on

the Cultivation of Students' Entrepreneurial Values and Ability

Under the New Media.

Front. Psychol. 12:725610 doi: 10.3389/fpsyg.2021.725610

\section{Influence of Entrepreneurial Psychology and Spirit on the Cultivation of Students' Entrepreneurial Values and Ability Under the New Media}

\author{
Weiwei Wang ${ }^{1}$ and Ying Jiang ${ }^{2 *}$ \\ ${ }^{1}$ College of Media and International Culture, Zhejiang University, Hangzhou, China, ${ }^{2}$ College of Foreign Languages, \\ Shandong University, Jinan, China
}

This article studies the influence of entrepreneurial spirit on college students' entrepreneurial ability and entrepreneurial values. Firstly, the impact of entrepreneurial psychology and entrepreneurial spirit on entrepreneurial values is analyzed. Secondly, the role of entrepreneurial values in innovation and entrepreneurship education is analyzed and summarized under new media. Then, based on entrepreneurial psychology and entrepreneurial spirit, a Questionnaire Survey (QS) is designed to investigate the entrepreneurial values of students in one university in Shaanxi Province, China. The QS analysis suggests that most respondents hold a positive attitude, and their attitude is on the rise. The QS results of "Reasons for entrepreneurial failure" show that $40.37,31.9,25.98$, and $11.75 \%$ of respondents think they lack financial support, business skills, ability, and understanding of policies and laws, respectively. The QS results of "What factors influence entrepreneurial values?" reveal that $39.43 \%$ of the respondents chose the "Models of successful entrepreneurs," successful entrepreneur models can effectively encourage students to receive entrepreneurship education, followed by $28.94 \%$ who choose "Achieve their own life goals." In terms of "Solutions against entrepreneurial risks," nearly $70 \%$ of the students have chosen the negative options. In terms of "Which is the most important entrepreneurial quality?" more students choose entrepreneurial values rather than entrepreneurial quality, proving that students generally lack entrepreneurial values. Given these problems, corresponding countermeasures are put forward to strengthen entrepreneurial psychology and entrepreneurship education, in an attempt to cultivate college students' entrepreneurial values and entrepreneurial ability under the new media. The results provide some data support for the impact of college students' entrepreneurial values and entrepreneurial ability.

Keywords: new media, entrepreneurial spirit, entrepreneurial values, entrepreneurial ability, positive impact 


\section{INTRODUCTION}

\section{Research Background}

Different countries and regions have adopted distinct methods to develop and implement entrepreneurship education. In the West, entrepreneurship education involves students' values cultivation, quality education, and ideological education; the curriculum is designed with clear educational objectives, and a unique and complete structural system has been formed for the cultivation of students' entrepreneurial values and entrepreneurial ability. In China, however, the cultivation system of students' entrepreneurial values and entrepreneurial ability is still far from perfect. Therefore, there is a need to absorb the international educational experience, draw lessons from foreign educational systems, and improve the cultivation of students' entrepreneurial education regarding China's national conditions and the actual situation of Chinese students. The advent of the new media era has witnessed China's "mass entrepreneurship and innovation" trend sponsored and guided by the Communist Party of China (CPC) and the state. It is self-evident that innovation and entrepreneurship play a crucial role in current socio-economic development. Independent entrepreneurship is becoming a new economic phenomenon in China. Moreover, under wide-spreading new media, college students need to adapt themselves to the characteristics of the times by adjusting their way of life and work, which put forward higher standards for students' mastery of theoretical knowledge and professional skills, as well as innovation and entrepreneurship quality. Therefore, it is urgent for higher institutions to set up innovation and entrepreneurship courses, support college students' entrepreneurship, especially, those with active entrepreneurial ideas, and aim specifically to cultivate a sufficient number of entrepreneurial talents for the Chinese modernization process.

\section{Related Work}

Under the background of new media, many researchers, including Chinese and Western scholars, have explored students' entrepreneurial values in entrepreneurship practice (Qian et al., 2018; Wang and Zhang, 2020). Argued that personalized education was an innovative educational approach that respected individual differences. With the progression of times, the number of innovative and entrepreneurial talents has become one of the key indexes of comprehensive national strength. Thus, there is a rising demand for higher institutions to respect the creativity and subjectivity of college students while cultivating their independent thinking and problem-solving abilities to lay a solid foundation for students' future innovation and entrepreneurship. Thereupon, some scholars have comparatively analyzed the current situation of personalized education in China and the West to promote the development of students' autonomy, along with the existing problems and solutions (Jin et al., 2019). Proposed a new model to verify the effectiveness of entrepreneurship education from three dimensions: entrepreneurial ability, barriers, and intention on 308 students of entrepreneurship education in one Chinese university. As a result, the effectiveness of entrepreneurship education was verified in terms of the improvement of entrepreneurial ability, the decrease of entrepreneurial barriers, and the change of entrepreneurial intention (Wu et al., 2018). Believed that entrepreneurship education could help rural enterprises create higher economic value, finding that respondents thought entrepreneurship education was influential to local/regional entrepreneurship ecosystems, and most respondents had benefited from the course, whereas the degree of the benefit lowered after the course ended (Hagebakken et al., 2021). Believed that entrepreneurship education was critical to stimulate people's interest in entrepreneurship, analyzed the characteristics of entrepreneurs, and found a customized cultivation model for young rural entrepreneurs in the agricultural industry. Specifically, the entrepreneurial factors affecting agricultural college students are analyzed to continue to run their parents' farms. The results showed that risk-taking, organizational ability, leadership, and effort affected their resolution to continue agriculture, while opportunity, patience, and other factors have little effect (Ayu and Nauly, 2020; Feng and Chen, 2020). Found that there were significant differences between teachers and students in all dimensions of the Employability Scale and Entrepreneurial Ability Scale, but there was no significant difference in gender. This suggested that there was a close relationship between college students' entrepreneurial ability and employment (Karayol and Taze, 2020).

\section{Research Purpose and Significance}

The purpose is to analyze the impact of entrepreneurial spirit on the cultivation of contemporary students' entrepreneurial values and entrepreneurial ability under the background of new media, together with the existing problems. Accordingly, some effective solutions are given, thus providing a direction for the formation of students' entrepreneurial values and entrepreneurial ability. Innovatively, the impact of entrepreneurship on the cultivation of students' entrepreneurial values and entrepreneurial ability is studied against the background of new media, utilizing new media as a method to cultivate correct entrepreneurial values in entrepreneurial education, and thereby providing new ideas for the cultivation of students' entrepreneurial values and entrepreneurial ability.

\section{CONTENT AND SIGNIFICANCE OF INNOVATION AND ENTREPRENEURSHIP EDUCATION, AND ENTREPRENEURIAL VALUES}

\section{Innovation and Entrepreneurship Education and Entrepreneurial Values}

With rapid economic development, people's understanding of entrepreneurship has been in constant variations. Today, entrepreneurship specifically refers to the establishment of new enterprises, a process of new career exploration. In essence, entrepreneurship is an innovative process, and entrepreneurs tend to have a positive outlook on life 
(Bogatyreva et al., 2019; Whitcher, 2019) following decades of development, entrepreneurship is still a new research field with fascinating prospects, but there has not been a consensus definition, and researchers generally hold that entrepreneurship contains three elements: product development, innovation, and entrepreneurial spirit. Firstly, entrepreneurship can promote employment, and create more jobs, promoting the sustainable and steady development of the social economy. In turn, successful entrepreneurship also needs various forms of social assistance. Evaluated students' experience of using mobile-based Classroom Response System (CRS) technology in entrepreneurship courses (Wu Y. et al., 2019). Secondly, in terms of innovation, entrepreneurship itself is an innovative process. Under the booming information age, successful entrepreneurs are no doubt innovators as well. Lastly, entrepreneurial spirit is the determination to tackle difficulties and risks of entrepreneurs during the entrepreneurial process, which is the foundation of entrepreneurship (Rogoza et al., 2018; Gonzalez, 2019).

Entrepreneurship can also be decomposed from the dimension of values: including the entrepreneur value, national value, and social value, the realization of which is the primary driving force for most college entrepreneurs (Prihatini and Hidayatullah, 2019; Eklund et al., 2020; Deng et al., 2021). Researchers interpret entrepreneurial values from different perspectives. Some point out that entrepreneurial values are entrepreneurs' recognition of entrepreneurial goals based on their individual needs and the criteria for entrepreneurial behaviors. Accordingly, college students' entrepreneurial activities originate from their entrepreneurial needs, like survival and starting a business (Morgan, 2019; Wang, 2019). In particular, the sense of social responsibility is essential for successful entrepreneurship apart from strong individual demand. Correct values are arguably the foundation of entrepreneurship and the key competitive advantage of entrepreneurs, guiding the entrepreneurial process. Explored the use and user satisfaction of social media in entrepreneurship from the perspective of learners ( $\mathrm{Wu}$ and Song, 2019). Thereupon, the main content of college entrepreneurship in China is constructed from the following aspects:

1. Indigenous emotion. From ancient times to today, people always have been endowed with different missions and emotions of that era, and indigenous emotion, in particular, has deeply affected the Chinese, which is, thus, part of Chinese college students' entrepreneurship that serves the Chinese dream of rejuvenation. Surely, the entrepreneurial path is paved with challenges and risks, as well as temptations from mammonism, hedonism, and egoism, with which the entrepreneurial process might come to a premature end unless college entrepreneurs have a strong indigenous emotion and willpower. Besides, Chinese college entrepreneurs are supposed to have the comprehensive ability of national cultural integration. Entrepreneurship bolsters individuals' sense of self-worth, and it is deemed an act to serve the Chinese nation (Lee and Raschke, 2020; Yang, 2020).
2. Social dedication. Social dedication is the essential feature of socialist professional ethics and the major content of entrepreneurial values in China. It has been argued that the value of life first lies in social dedication, and as a social unit, people should not merely strive for their own happiness but also endeavor to contribute to national well-being. With the upcoming new era, more social spheres are supporting entrepreneurial activities, in which college students are expected to play a leading role. Therefore, college entrepreneurship education should help the students acquire the skills of innovation and entrepreneurship under the new media background and develop a sense of social responsibility (Wang, 2020).

3. Innovation and development. Innovation is the soul and source of national development, which should be integrated into contemporary college students' entrepreneurial process. Meanwhile, innovation focuses on newness, improvement, and spread of ideas or technologies, and the purpose is to create business value, namely, the incremental improvement to existing products. China's future development is believed to lies in the hand of college students who possess comprehensive qualities, especially, innovative spirit. Therefore, the education of entrepreneurial values in higher institutions under the new media should pay more attention to students' entrepreneurial development, strengthen their independent innovation ability, and stimulate their motivation for innovation and entrepreneurship (Chen, 2019; Wu, 2020).

4. Risk-taking spirit. Entrepreneurship is a long-term enduring process during which entrepreneurs face various challenges (risks) and should keep on working to transform their environment. Fortunately, the risk-taking spirit can be cultivated through acquired efforts, which, therefore, should be strengthened through college education of innovation and entrepreneurship under the background of new media (Klein, 2019).

5. Collectivism. In today's ultra-competitive society, challenges and opportunities go hand in hand. Crossborder cooperation is becoming increasingly important in economic globalization, and the sense of cooperation and collaboration is growing into the basic requirements for entrepreneurial talents. Therefore, during the education for students' innovation and entrepreneurship, higher institutions should pay full attention to cultivating students' entrepreneurial awareness and competitiveness, as well as their cooperation ability.

Further, entrepreneurial psychology also has a particular impact on the formation of college students' entrepreneurial values. It has been argued that the psychological quality of entrepreneurial talents should be divided into seven dimensions: confidence, willpower, imagination, exploration, flexibility, and cooperation awareness. Others believe that entrepreneurial psychology should include innovative thinking, basic theoretical knowledge, innovative will, and innovative ability. Entrepreneurial psychology during entrepreneurship 
involves knowledge, thinking, ability, concept, and will. The cultivation of college students' entrepreneurial psychology can be divided into four parts: entrepreneurial awareness, entrepreneurial will, entrepreneurial ability, and entrepreneur personality. The influence of entrepreneurial psychology on college students' entrepreneurial values can be summarized into seven aspects: 1. Innovation, entrepreneurship, and cognition, this aspect includes innovative thinking, cognition of potential innovation and entrepreneurship opportunities, entrepreneurs' cognitive deviation, and relevant thinking training. 2. Innovation, entrepreneurship, and personality characteristics, this aspect includes the entrepreneurs' personalities in different stages of the entrepreneurial process, the prediction of personalities, and the entrepreneurial failure-prone personalities. 3. Innovation, entrepreneurship, and ability, this includes the personal ability required for innovation and entrepreneurship, the training mode of personal ability, and the role of unique ability in a specific period. 4. Innovation, entrepreneurship, and psychopathology, this aspect includes the relationship between entrepreneurship and psychopathology, the prevalence of entrepreneurs' psychological disorders, entrepreneurs' psychological regulation, common psychological disorders, and entrepreneurs' perception of employees' psychological state. 5 . Innovation, entrepreneurship, and emotion, this aspect includes the impact of emotion on cognition, the test and cultivation of EQ. 6. Innovation, entrepreneurship, and leadership psychology, this aspect includes the research on the characteristics of leaders, the matching degree between leaders and the environment, the quality of leaders, and the leadership of college students. 7. Innovation, entrepreneurship, and positive psychology, this aspect includes the content research of positive psychology, the impact of positive psychology on entrepreneurs, and the intervention and training research of positive psychology.

\section{Characteristics and Status of the New Media Technology}

With the advancement of computer and information technologies, various types of new media forms emerge, which are attracting more audiences through interactive changes to the traditional techniques and communication modes over the Internet. Used a quasi-experimental design and qualitative methods to test the effectiveness of the PowToon tool to present business plans. New media technology has three technical characteristics: (1) Sharing, that is, the new media technology breaks the time-spatial limitation by providing people with abundant information exchange. (2) Diversity, that is, new media forms are more diverse, which can be flexibly expressed through a single form or combination of audio, video, and image, among others (Ding, 2020). (3) Multi-directional interaction, that is, the information sending terminal always changes from a single point to multi-point and multi-direction (Wu W. et al., 2019; Xiao et al., 2019).

College students are considered to be a well-educated and more knowledgeable social group with a strong desire and competency to explore new things and ideas, who are very active in the use of new media. With the development of the Internet, the new media, especially, mobile social media, has gradually become the main information acquisition and exchange channel for college students. New media have a great impact on the interpersonal communication, learning and life, and innovative thinking of college students (European Physical and Rehabilitation Medicine Bodies Alliance, 2018; Soegoto and Luckyardi, 2020). Thus, there is a need for higher institutions to carry out innovation and entrepreneurship activities through the new media to help students improve their innovation and entrepreneurship ability. Nowadays, college innovation and entrepreneurship education require more information sharing and multiple interactions. New media has brought various new resources along with challenges for college innovation and entrepreneurship education. For example, higher institutions can implement the online platform of innovation and entrepreneurship education based on new media technology, such as Massive Open Online Courses (MOOCs), which puts classroom teaching over the Internet platform and changes traditional face-to-face education into online education. The innovation and entrepreneurship education platform can provide information technology services for students through the Internet of Things (IoT), cloud computing technology, encryption algorithm, and other technologies, and integrate educational resources and scientific research, together with the latest entrepreneurship policies and theories to create targeted education courses for students (Huang, 2019). New media technology has great application potential in college innovation and entrepreneurship education because it can integrate massive teaching content and classic cases to provide extended after-class readings for the benefit of students. Moreover, with super interactivity, the new media can provide rich entrepreneurial information for college students, as well as various entrepreneurial channels to encourage college students' entrepreneurship (Yan, 2018).

\section{Questionnaire Survey Design of College Students' Entrepreneurial Values}

The research subject is the college students from one university in Xi'an. Totally, 150 Questionnaire Surveys (QSs) are distributed, and 142 valid QSs are recovered, with an effective rate of $94.6 \%$, of which the Science and Engineering students account for $52.3 \%$ of the total sample, the Economics and Management students account for $29.1 \%$, and other majors account for $18.6 \%$. The QS is composed of four parts: the first part is the basic information of the respondents, including gender, grade, school, major, and family location; the purpose is to test whether there are significant differences in observed variables in different populations. The second part is to master the students' cognition of entrepreneurship. The third part is the College Students' Innovative Spirit Scale, which is used to measure the innovative spirit of the respondents. The fourth part is College Students' Entrepreneurial Ability Scale, which is used to observe students' entrepreneurial ability. College Students' Innovative Spirit Scale includes four dimensions: flexibility (questions 1, 4, 6, 12, 15, 16, and 22), standard innovation 
(questions 2, 8, 17, 19, 21, 23, and 25), criticism (questions $3,7,11,13,18$, and 20), and reflection (questions 5, 9, 10, 14 , and 24), with a total of 25 questions. For fear of thinking set that might affect the measurement results, questions 4, $11,13,14,20,22$, and 25 adopt the reverse scoring method. The Likert's 5-point scoring method is adopted, in which "completely inconsistent," "not quite consistent," "uncertain," "relatively consistent," and "fully consistent" are assigned " $1-5$ " points, respectively. The average total score of the scale is used to measure the level of innovation spirit: 1-2 points indicate low level, 2-3 points represent middle and lower level, 3-4 points refer to the middle and upper level, and 4-5 points stand for high level. College Students' Entrepreneurial Ability Scale includes opportunity exploration ability (questions 1, 2, 3 , and 4), organization and management ability (questions 5, 6 , and 7), strategic decision-making ability (questions 8, 9, and 10), resource integration ability (questions 11, 12, 13, and 14), innovation and creativity ability $(15,16$, and 17$)$, and frustration tolerance ability (questions19, 20, 21, and 22), totaling 22 questions. Likewise, Likert's 5-point scoring method is employed: "completely inconsistent," "not quite consistent," "uncertain," "relatively consistent," and "fully consistent" are assigned 15 points, respectively; the average total score of the scale is used to measure entrepreneurial ability: 1-2 points indicate low level, 2-3 points refer to the middle and lower level, 34 points mean middle and upper level, and 4-5 points stand for high level. Further, SPSS 25.0 is used to statistically analyze the sample data.

Main contents of the QS:

(1) Factors influencing college students' entrepreneurial choice: A. Realization of personal ideals and values; B. High degree of freedom; C. High earrings; D. Poor employment situations and affected by others.

(2) Essential elements in the entrepreneurial process: A. Education; B. Ability; C. Relationship; D. Others.

(3) Solutions against entrepreneurial risks: A. Take a positive attitude; B. Hesitate; C. Give up; D. Let nature take its course.

(4) What factors lead to entrepreneurial failure? A. Lack of financial support; B. Lack of basic business skills; C. Lack of ability; D. Lack of understanding of policies and regulations.

(5) What factors influence entrepreneurial values? A. Achieve their own life goals; B. Models of successful entrepreneurs; C. Government influence; D. School influence.

(6) Which is the most important entrepreneurial quality? A. Innovation-driven development; B. Adventure; C. Win-win cooperation and perseverance; D. Honesty and trustworthiness.

(7) What types of new media do college students use? A. Sina portals; B. QQ; C. WeChat; D. Others.

(8) Why do college students use new media? A. Entertainment; B. Subscribe to the current news; C. Propagation; D. Others.

(9) Time distribution of college students' use of new media: A. 1-2 h; B. 3-4 h; C. 5-6 h; D. More than 6 h.

\section{ANALYSIS AND OPTIMIZATION OF COLLEGE STUDENTS' ENTREPRENEURIAL VALUES}

\section{Reliability and Validity Analysis}

Table 1 shows the statistics of the reliability of the scale.

Table 1 demonstrates that the Cronbach's alpha coefficient is used to verify the internal consistency and reliability of the QS, which ensures the scoring consistency of each item. The measured value of $\alpha$ is 0.797 , indicating that the QS has good reliability and internal consistency.

\section{Analysis of the Results of the Questionnaire Survey on Entrepreneurial Factors}

The QS results of the entrepreneurial factors are shown in Figures 1-3.

Figure 1 presents the distribution of students' answers to factors affecting entrepreneurial choice. A total of $25.78 \%$ of them choose "The realization of personal ideals and values," which is also the values of the current entrepreneurship education; 26.21 and $11.12 \%$ of them choose "High degree of freedom" and "High earnings," respectively, with some utilitarian ideas; while $16.35 \%$ of them choose "The poor employment situations," under which self-employment is believed to a new choice. Overall, college students' entrepreneurial values are positive, and "The realization of personal ideals and values" is most influential to their entrepreneurial choices, while, by comparison, they pay lesser attention to the realization of their national and social values.

Figure 2 illustrates the distribution of students' answers to the essential elements of the entrepreneurial process. Specifically, $21.65,33.94$, and $31.97 \%$ of them think education, ability, and

TABLE 1 | Reliability statistics.

\begin{tabular}{lcc}
\hline Cronbach's alpha & $\begin{array}{c}\text { Standardized } \\
\text { Cronbach's alpha }\end{array}$ & Number of items \\
\hline 0.791 & 0.761 & 7
\end{tabular}

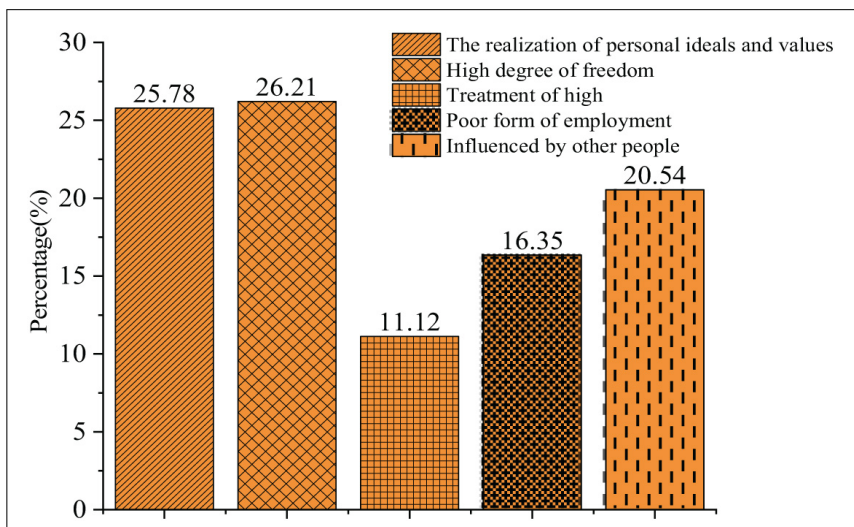

FIGURE 1 | Factors influencing the entrepreneurial choice. 
relationship are the most essential, respectively. Hence, most college students believe that education and ability are more important in the entrepreneurial process, but other factors, like money, are also indispensable. It has been argued that an entrepreneur's ability and education are internal factors while other factors are the external factors, which are both essential for successful entrepreneurship.

Figure 3 exhibits the distribution of students' answers to the solutions against entrepreneurial risks. A total of $30.35,30.29,25.23$, and $14.13 \%$ of them choose "Take a positive attitude," "Hesitant," "Give up," and "Let nature take its course," respectively. Thus, college students lack social experience and their risk-bearing ability is incompetent; nearly $70 \%$ of the respondents have shown no positive attitude against entrepreneurial risks. Given this, there is a need for higher institutions to attach great importance to the guidance of values and entrepreneurial psychology in entrepreneurship education.

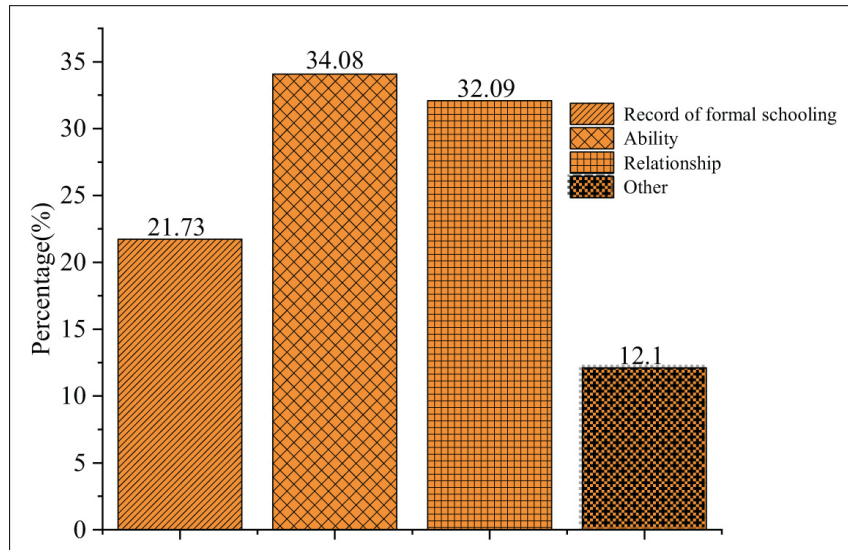

FIGURE 2 | Essential elements for the entrepreneurial process.

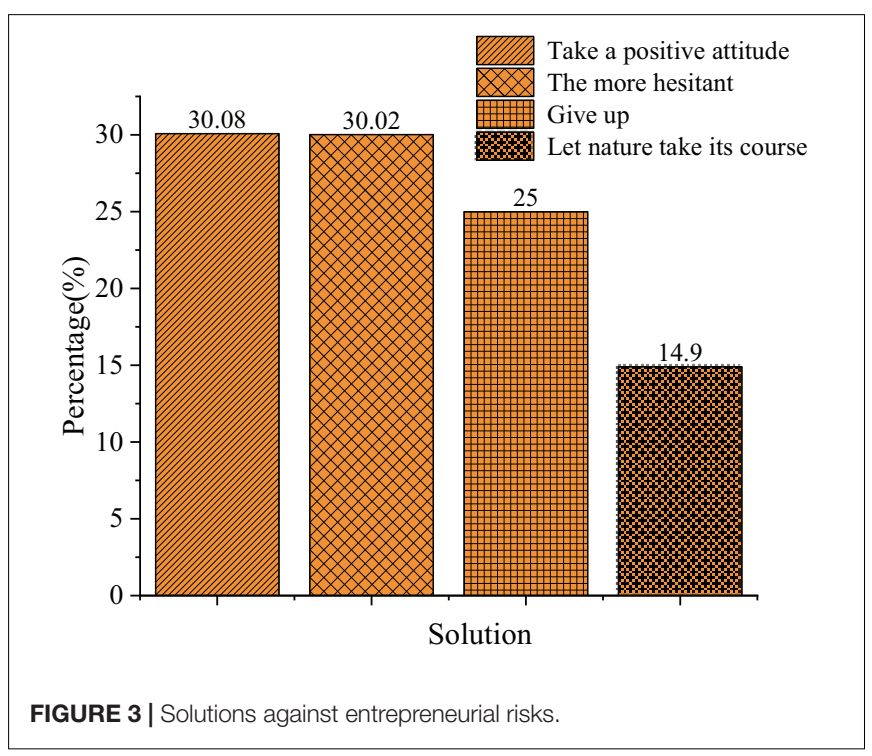

\section{Entrepreneurial Values Questionnaire Survey Results Analysis}

The QS results of entrepreneurial values are shown in Figures 4-6.

Figure 4 shows the distribution of students' answers to "What factors lead to entrepreneurial failure?" Specifically, 40.37,
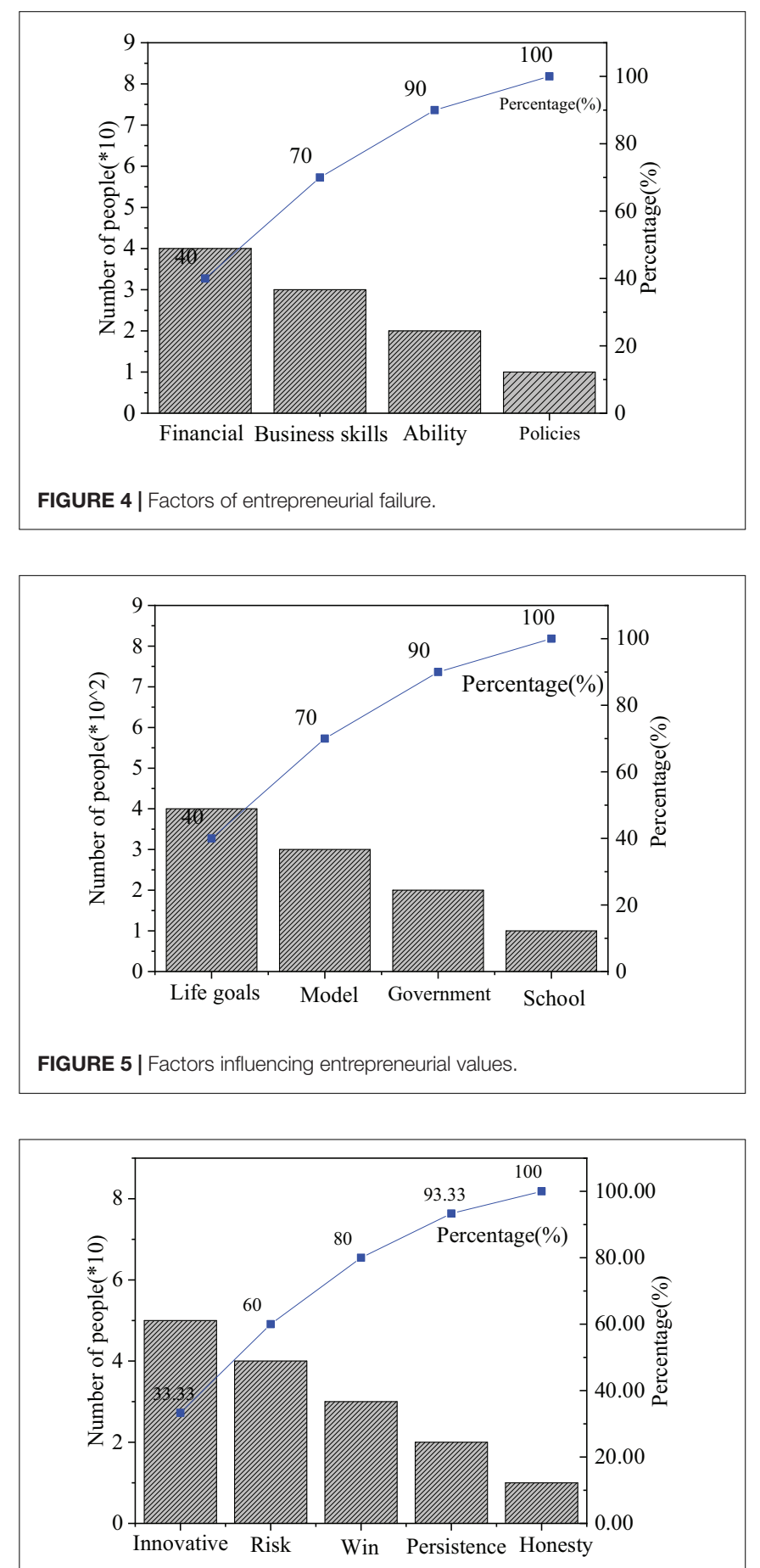

FIGURE 6 | Importance of entrepreneurial quality. 
31.9, 25.98, and $11.75 \%$ of them think they lack financial support, business skills, ability, or understanding of policies and laws, respectively. Thus, entrepreneurship is a practical process, and entrepreneurship education needs to be combined with practice; also, it has been recognized by students that the skills and ability of entrepreneurs play an important role in the entrepreneurial process; besides, financial support affects the whole life cycle of entrepreneurship. Overall, most students hold correct entrepreneurial values.

Figure 5 displays the distribution of students' answers to "What factors influence the entrepreneurial values?" $39.43 \%$ of them choose "Models of successful entrepreneurs," showing that the power of the model is infinite, and entrepreneurial spirit can strongly promote entrepreneurship, followed by $28.94 \%$ who choose "Achieve their own life goals"; those who have chosen "Government influence" or "School influence" both account for over $15 \%$. Thus, as the enforcement authorities of national rights, the government supports college students' entrepreneurship and affects the development of entrepreneurship education by implementing relevant policies; higher institutions might be exactly where students form correct entrepreneurial values.

Figure 6 reveals the distribution of students' answers to "Which is the most important entrepreneurial quality?" Overall, students who choose entrepreneurial values outnumber those who choose practical entrepreneurial ability. Hence, students generally lack entrepreneurial values, and there is a need for higher institutions to pay attention to the cultivation of students' spiritual quality in the education of entrepreneurial values. The value and quality of entrepreneurs are of great significance to the development of the country and individuals.

\section{The Questionnaire Survey Results of College Students' Use of New Media}

The QS results of college students' use of new media are shown in Figures 7-9.

Figures 7-9 imply that such new media platforms as Sina portal, QQ, and WeChat are widely used among college students, with a use rate of 84,72 , and $65 \%$, respectively. Among the three groups surveyed, freshmen are more inclined to use WeChat, while seniors prefer QQ; their purpose to use new media differ greatly; more freshmen use new media for entertainment, while the seniors are interested in real-time news and daily communication over new media platforms. The QS results of "Time distribution of college students' use of new media" show that over $50 \%$ of the respondents use new media for at least 5 h daily.

Thereupon, the following problems are summarized in the cultivation of college students' entrepreneurial values and entrepreneurial ability under the new media environment:

(1) Teaching thinking and teaching philosophy are relatively backward.

Given the new media environment, the school is still mainly responsible for the cultivation of college students' entrepreneurial values and entrepreneurial ability, yet family support is also essential. Currently, however, only a few school

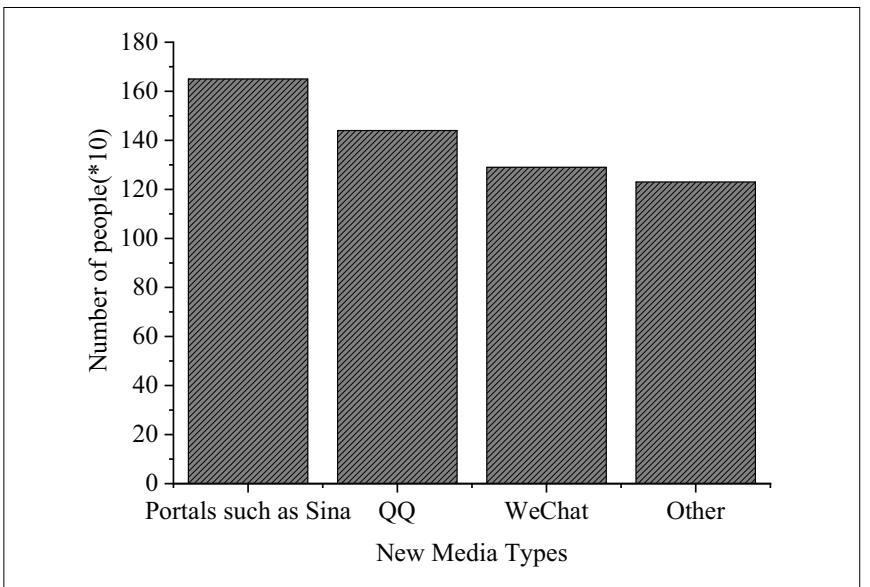

FIGURE 7 | Questionnaire Survey of the types of new media used.

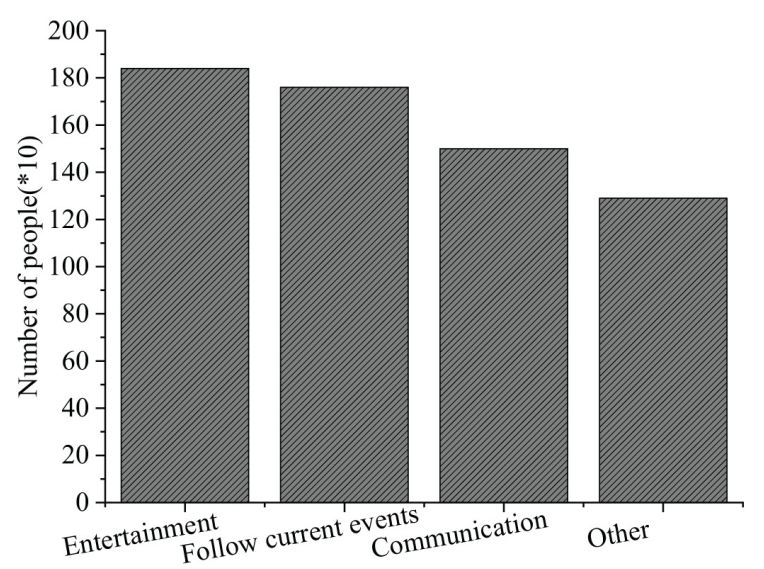

FIGURE 8 | Questionnaire Survey of purposes for using new media.

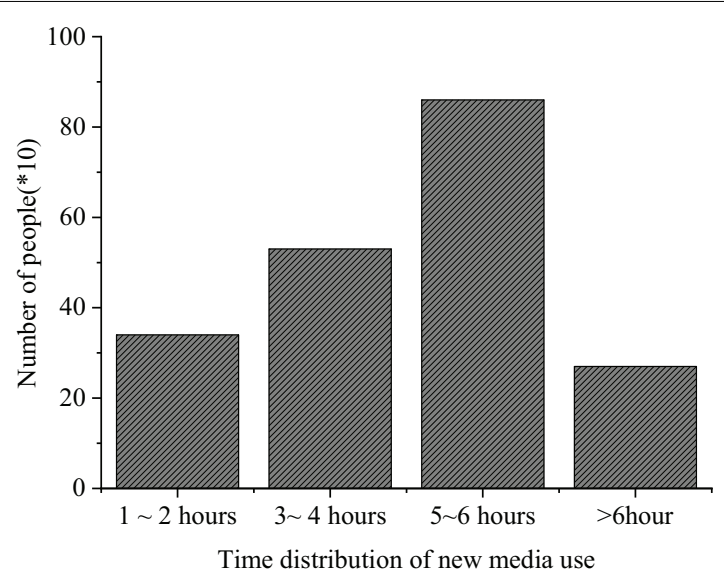

FIGURE 9 | Questionnaire Survey of the new media utilization time.

departments are involved in the organization and coordination of entrepreneurial courses, leading to an incomplete innovation and entrepreneurship education system. 
(2) In terms of the teaching content, few practices have been implemented compared with theories of innovation and entrepreneurship education in higher institutions, which hinders the cultivation of students' entrepreneurial values and entrepreneurial ability but also has a negative impact on their personal development.

\section{CULTIVATING STRATEGIES OF COLLEGE STUDENTS' ENTREPRENEURSHIP EDUCATION UNDER THE NEW MEDIA}

The above research suggests that entrepreneurship education in Chinese higher institutions is in the theoretical teaching stage and lacks practical teaching reform to effectively cultivate students' entrepreneurial concept and entrepreneurial ability. In addition to strengthening the cultivation of college students' entrepreneurial psychology and entrepreneurial spirit, the cultivation strategy might also include the following aspects.

(1) Students might benefit from unified ideas to better understand entrepreneurship education. It is the responsibility and obligation of higher institutions to cultivate talents with an entrepreneurial spirit for the country through entrepreneurship education. There is a need for higher institutions to help students understand the basic theory and business law in entrepreneurship education and improve their environmental adaptability and risk controllability. Above all, it is essential to cultivate students' entrepreneurial spirit through entrepreneurship education, namely, enterprising spirit, professionalism, integrity, dedication, and sense of social responsibility.

(2) There is a need to formulate an innovation training plan and build an integral entrepreneurship education system to promote entrepreneurship education. To cultivate students with a more comprehensive entrepreneurial spirit, there should be a series of education of entrepreneurship management theory and entrepreneurship training. The teaching content should be customized for students in different grades.

(3) It might benefit the students to cultivate entrepreneurial awareness in the entrepreneurial atmosphere through various school activities, which provides students with reference and guidance for entrepreneurship, as well as a platform to exercise their entrepreneurial ability, thus stimulating students innovative awareness and entrepreneurial spirit in the form of community organizations.

(4) Entrepreneurial resources in higher institutions might be integrated to improve entrepreneurial management efficiency. Multiple factors can be combined with the cultivation of entrepreneurship education in higher institutions, such as the support of national entrepreneurship policies, the specific guidance of enterprises, and various organizations, to form a complete and effective entrepreneurship education system that integrates existing entrepreneurship resources and improves entrepreneurship management efficiency.

The optimization strategies (1-4) are favorable for the implementation of effective and efficient entrepreneurship education and training under the new media era and have a positive impact on the cultivation of students' entrepreneurial values and entrepreneurial ability.

\section{CONCLUSION}

The purpose is to analyze the impact of entrepreneurial spirit on the cultivation of contemporary students' entrepreneurial values and entrepreneurial ability under the background of new media, study the existing problems in the cultivation of entrepreneurship education in the higher institution through QS. The QS results show in terms of the question "What are the factors affecting entrepreneurial values," $39.43 \%$ of respondents choose the "Models of the successful entrepreneur," showing that the successful entrepreneur model can encourage students to receive entrepreneurship education; $28.94 \%$ of the students choose to "Achieve their own life goals"; those who have chosen "Government influence" or "School influence" both exceed 15\%. The students' answers to "The reasons for entrepreneurial failure" indicate that 40.37, 31.9, 25.98, and $11.75 \%$ of the respondents think they lack financial support, business skills, ability, or understanding of policies and laws, respectively; entrepreneurship is a process of practice, and entrepreneurship education needs to be combined with practical activities; the skills and ability of entrepreneurs play an important role in the entrepreneurial process and have been recognized by students. Additionally, financial support affects the whole life cycle of entrepreneurship. This article provides great help for the cultivation of entrepreneurial values and entrepreneurial ability of college students in the future. However, there are some limitations: at the theoretical level, the results of targeted suggestions and policies have not been verified and supported by other data, and there is no deeper theoretical and practical exploration. The proposed training strategies on students' entrepreneurial values and entrepreneurial ability can provide a new theoretical basis and optimization direction for entrepreneurship education in higher institutions and help students receive better entrepreneurship education in the future.

\section{DATA AVAILABILITY STATEMENT}

The raw data supporting the conclusions of this article will be made available by the authors, without undue reservation.

\section{ETHICS STATEMENT}

The studies involving human participants were reviewed and approved by the Shandong University Ethics Committee. The patients/participants provided their written informed consent to participate in this study. Written informed consent was obtained from the individual(s) for the publication of any potentially identifiable images or data included in this manuscript. 


\section{AUTHOR CONTRIBUTIONS}

WW: conceptualization, methodology, and writing - original draft. YJ: software, supervision, data curation, project administration, and resources.

\section{REFERENCES}

Ayu, S. F., and Nauly, M. (2020). Entrepreneurship factor's affecting the youth decided to continue their family farm. J. Phys. Conf. Ser. 1542:012052. doi: $10.1088 / 1742-6596 / 1542 / 1 / 012052$

Bogatyreva, K., Edelman, L. F., Manolova, T. S., Osiyevskyy, O., and Shirokova, G. (2019). When do entrepreneurial intentions lead to actions? The role of national culture. J. Bus. Res. 96, 309-321. doi: 10.1016/j.jbusres.2018.11.034

Chen, M. (2019). The impact of expatriates' cross-cultural adjustment on work stress and job involvement in the high-tech industry. Front. Psychol. 10:2228. doi: 10.3389/fpsyg.2019.02228

Deng, X., Guo, X., Wu, Y. J., and Chen, M. (2021). Perceived environmental dynamism promotes entrepreneurial team member's innovation: explanations based on the uncertainty reduction theory int. J. Environ. Res. Public Health 18:2033. doi: $10.3390 /$ ijerph 18042033

Ding, M. (2020). Influence of new media technology on the reading habits of contemporary college students. J. Phys. Conf. Ser. 1533:042087. doi: 10.1088/ $1742-6596 / 1533 / 4 / 042087$

Eklund, J., Levratto, N., and Acs, Z. J. (2020). Entrepreneurship and failure: two sides of the same coin? Small Bus. Econ. 54, 373-382. doi: 10.1007/s11187-0180039-z

European Physical and Rehabilitation Medicine Bodies Alliance (2018). White book on physical and rehabilitation medicine (PRM) in Europe. chapter 9. education and continuous professional development: shaping the future of PRM. Eur. J. Phys. Rehabil. Med. 54, 279-286. doi: 10.23736/S1973-9087.18. 05153-5

Feng, B., and Chen, M. (2020). The impact of entrepreneurial passion on psychology and behavior of entrepreneurs. Front. Psychol. 11:1733. doi: 10. 3389/fpsyg.2020.01733

Gonzalez, M. (2019). Inspiring entrepreneurial spirit. J. Stud. Int. Educ. 19:2. doi: $10.1111 / 1468-4446.12787$

Hagebakken, G., Reimers, C., and Solstad, E. (2021). Entrepreneurship education as a strategy to build regional sustainability. Sustainability, 13:2529.

Huang, Q. (2019). Research on the hybrid teaching reform of online open course three-dimensional classroom. IEEE Sens. J. 2, 55-61.

Jin, C., Luo, Y., Sun, H., Shen, G., and Han, Y. (2019). Development of college students' innovation and entrepreneurship ability under the model of personalized education. Asian Agric. Res. 11, 86-88.

Karayol, M., and Taze, M. (2020). Investigation of entrepreneurship levels and employability perception of undergraduate students studying sports sciences. J. Stud. Int. Educ. 13:35.

Klein, C. (2019). DGNeurologie and new media-an interactive dialog on the opportunities and challenges in our field. DG Neurologie 2, 77-79. doi: 10.1007/ s42451-019-0057-3

Lee, M. T., and Raschke, R. L. (2020). Innovative sustainability and stakeholders' shared understanding: the secret sauce to "performance with a purpose". J. Bus. Res. 108, 20-28.

Morgan, B. (2019). Asher's towering ambition. Upstream Int. Oil Gas Newspaper 24:40.

Prihatini, Y. O., and Hidayatullah, T. (2019). Building sports equipment among students through media as a trend. IOP conference series. Mater. Sci. Eng. $R$ Rep. 662:032069.

Qian, J., Song, B., Jin, Z., Wang, B., and Chen, H. (2018). Linking empowering leadership to task performance, taking charge, and voice: the mediating role of feedback-seeking. Front. Psychol. 9:2025. doi: 10.3389/fpsyg.2018.02025

Rogoza, R., Żemojtel-Piotrowska, M., Kwiatkowska, M. M., and Kwiatkowska, K. (2018). The bright, the dark, and the blue face of narcissism: the spectrum of

\section{FUNDING}

This work was supported by the National Social Science Foundation of China Project "A Study on National Cultural Confidence in Germany and its Implications for China" (18BKS062).

narcissism in its relations to the meta traits of personality, self-esteem, and the nomological network of shyness, loneliness, and empathy. Front. Psychol. 9:343. doi: 10.3389/fpsyg.2018.00343

Soegoto, E. S., and Luckyardi, S. (2020). Computerized entrepreneurship education - special review on life quality in digital era. J. Phys. Conf. Ser. 1477:032017. doi: 10.1088/1742-6596/1477/3/032017

Wang, L., and Zhang, E. (2020). Exploration and practice of teaching reform of industrial robot course based on application ability training. IOP conference series. Mater. Sci. Eng. R Rep. 780:032017.

Wang, T. (2019). Exploring the mode of entrepreneurship education based on the legal-business compound competency in China. Front. Psychol. 10:1055-1055. doi: 10.3389/fpsyg.2019.01055

Wang, Y. (2020). Research on innovative application of new media in visual communication design. J. Phys. Conf. Ser. 1550:032146. doi: 10.1088/1742 $6596 / 1550 / 3 / 032146$

Whitcher, J. (2019). An entrepreneurial spirit for innovation. Print. Impressions 62, 24-24.

$\mathrm{Wu}$, Q. (2020). Research on new media advertising marketing strategy in China under the "internet +" background. J. Phys. Conf. Ser. 1584:012020.

Wu, W., Wang, H., Zheng, C., and Wu, Y. J. (2019). Effect of Narcissism, psychopathy, and machiavellianism on entrepreneurial intention-the mediating of entrepreneurial self-efficacy. Front. Psychol. 10:360.

$\mathrm{Wu}$, Y., and Song, D. (2019). Gratifications for social media use in entrepreneurship courses: learners'. Front. Psychol. 10:1270.

$\mathrm{Wu}, \mathrm{Y} ., \mathrm{Wu}, \mathrm{T}$., and Li, Y. (2019). Impact of using classroom response systems on students' entrepreneurship learning experience. Comput. Hum. Behav. 92, 634-645. doi: 10.1016/j.chb.2017.08.013

Wu, Y. J., Yuan, C. H., and Pan, C. I. (2018). Entrepreneurship education: an experimental study with information and communication technology. Sustainability 10, 1-13.

Xiao, S., Kong, Q., Song, M., et al. (2019). Teaching reform of CNC technology course under the ideological and political education. IEEE Sens. J. 2, 36-41.

Yan, Y. (2018). Teaching research on higher vocational pre-school education of professional art course based on innovation and entrepreneurship education. CEI 9, 713-718.

Yang, X. (2020). Research on creative strategy of Chinese public service advertising based on new media technology. J. Phys. Conf. Ser. 1533:022088. doi: 10.1088/ $1742-6596 / 1533 / 2 / 022088$

Conflict of Interest: The authors declare that the research was conducted in the absence of any commercial or financial relationships that could be construed as a potential conflict of interest.

Publisher's Note: All claims expressed in this article are solely those of the authors and do not necessarily represent those of their affiliated organizations, or those of the publisher, the editors and the reviewers. Any product that may be evaluated in this article, or claim that may be made by its manufacturer, is not guaranteed or endorsed by the publisher.

Copyright (c) 2021 Wang and Jiang. This is an open-access article distributed under the terms of the Creative Commons Attribution License (CC BY). The use, distribution or reproduction in other forums is permitted, provided the original author(s) and the copyright owner(s) are credited and that the original publication in this journal is cited, in accordance with accepted academic practice. No use, distribution or reproduction is permitted which does not comply with these terms. 